\title{
PERBAIKAN MUTU FRAKSI KEROSIN MELALUI PROSES ADSORPSI OLEH KARBON AKTIF
}

\author{
Arnelli dan Asti Hanani \\ Laboratorium Kimia Fisik Jurusan Kimia FMIPA Universitas Diponegoro
}

\begin{abstract}
ABSTRAK
Proses adsorpi menggunakan karbon aktif telah digunakan untuk mengurangi kandungan senyawa sulfur dan meningkatkan kualitas warna pada fraksi kerosin. Hasil penelitian menunjukkan bahwa berat karbon aktif dan waktu kontak optimum pada proses adsorpsi adalah 150 gram dan 80 menit dengan pengurangan kandungan sulfur 32,2\% sedangkan kualitas warna meningkat 87,5 \% dengan demikian proses adsorpsi oleh karbon aktif lebih efektif dalam meningkatkan kualitas warna fraksi kerosin.
\end{abstract}

Kata kunci: Adsorpsi, karbon aktif, fraksi kerosin

\section{QUALITY ENHANCEMENT OF KEROSENE FRACTION THROUGH ADSORPTION PROCESS BY ACTIVE CARBON}

\begin{abstract}
ABSTRACK
Adsorption processes using activated carbon have been used to decrease concentration of sulfur compound and to increase dye quality of kerosene fraction. The result of research showed that weight of activated carbon and optimum contact time on adsorp proceses was 150 gram and 80 minutes with decrease sulfur compound consentrasion $32.2 \%$, beside that dye quality increase $87.5 \%$, so that adsorpsion proceses by this activated carbon more effective to increase dye quality of cerosine fraction. Keywords: adsorption, active carbon, kerosene fraction

\section{PENDAHULUAN}

Minyak bumi adalah bahan suatu bahan cair yang terdiri dari berbagai bahan organik yang ditemukan di bawah permukaan bumi. Komponen minyak bumi ini tergantung dari daerah ditemukan. Komponen utama dari minyak bumi adalah hidrokarbon murni $72 \%$, selain itu senyawa sulfur, nitrogen dan oksigen 1-6 \%. Salah satu senyawa hidrokarbon yang terdapat dalam minyak bumi adalah parafin dan yang mempunyai atom karbon 5-15 banyak terdapat dalam fraksi nafta, bensin, kerosin dan bahan bakar lainnya (Hardjono 1987).

Kerosin adalah fraksi destilat minyak bumi pada suhu $175-275^{\circ} \mathrm{C}$, merupakan produk yang amat penting dari minyak bumi karena manfaat kerosin bagi kehidupan sehari-hari amatlah

besar, antara lain sebagai bahan bakar di rumah tangga.

Fraksi kerosin adalah salah satu fraksi minyak bumi yang masih mengandung pengotor yang menyebabkan bau, disamping itu warna fraksi tersebut belum bagus untuk dipasarkan. Bahan penyebab warna pada fraksi minyak bumi pada umumnya disebabkan oleh komponen sulfur, nitrogen dan oksigen yang tersisa pada proses destilasi yang kurang sempurna serta bahan hasil kondensasi berbagai molekul dalam minyak bumi yang disebut Gum (Kirk and Othmer 1982). Upaya-upaya penghilangan pengotor yang dilakukan di kilang mini PPT Migas Cepu seperti pencucian dengan soda belum memberikan hasil yang sesuai dengan spesifikasi yang diharapkan.
\end{abstract}


Karena karbon aktif mempunyai luas permukaan yang besar 300-2500 $\mathrm{m}^{2} /$ gram maka pada penelitian ini digunakan karbon aktif untuk menyerap pengotor-pengotor penyebab bau dan warna melalui proses adsorpsi mengingat proses adorpsi adalah proses yang mudah dilakukan dan cukup efektif.

Krbon aktif merupakan karbon yang sudah diaktifkan sehingga mempunyai daya serap yang tinggi terhadap warna, bau, zat-zat beracun dan sebagainya. Sifat lain dari karbon aktif adalah amorf, berwarna hitam, tidak berbau, tidak berasa, tidak larut dalam air, asam, basa dan pelarut organik. Karbon aktif dapat dibuat melalui beberapa tahap uyaitu tahap karbonisasi $\left(600^{\circ} \mathrm{C}\right)$ sebagai langkah awal pembentukan struktur keropos dan tahap aktivasi untuk meningkatkan luas permukaan (Jankowska et. $a l, 1991)$.

Secara umum yang menyebabkan daya serap pada karbon aktif adalah adanya pori-pori mikro antar partikel yang sangat banyak jumlahnya, hal ini akan menimbulkan gejala kapiler yang menyebabkan daya serap. Luas permukaan karbon aktif yang sangat besar -5\% makropori dan mesopori dan 95\% mikropori sebesar 95\%menentukan dalam proses adsorpsi sehingga karbon aktif banyak digunakan sebagai adsorben. Pada kondisi tertentu ternyata hanya sebagian permukaan karbon aktif yang dapat menyerap zat yang tertentu pula, hal ini yang dinamakan situs aktif permukaan. (Cheremisinoff, 1978)

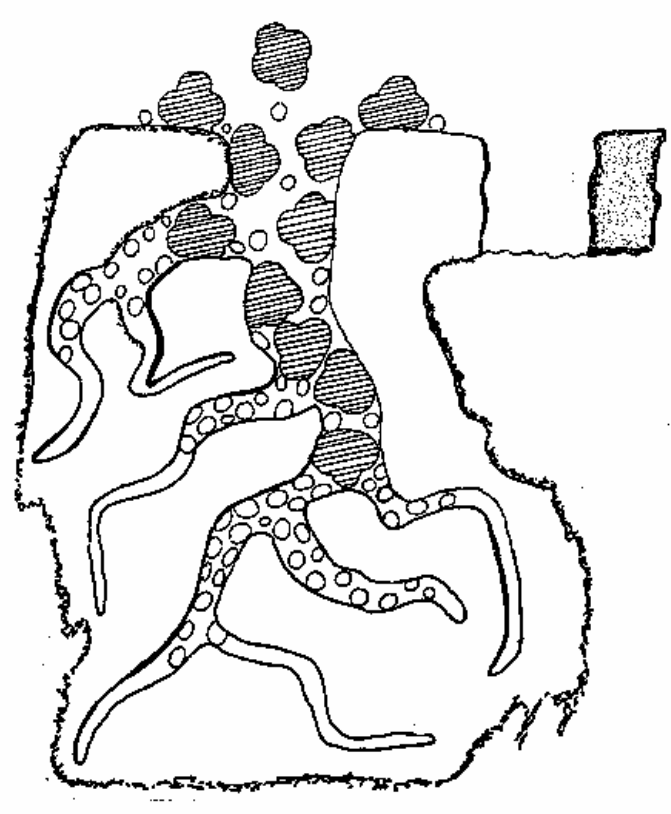

Gambar 1: Struktur pori karbon aktif.

Suatu molekul pada antarmuka atau permukaan mengalami ketidakseimbangan gaya, akibatnya molekul-molekul ini akan mudah menarik molekul-molekul lain sehingga keseimbangan gaya akan tercapai (Surdia,1992). Melekatnya atom atau molekul pada permukaan zat lain ini disebut adsorpsi, atau dengan kata lain proses adsorpsi adalah proses penyerapan suatu zat (adsorbat) oleh zat lain (adsorben) pada permukan, oleh karena itu sifat permukaan adsorben sangat menentukan pada proses adsorpsi, apakah permukaan tersebut berpori sehingga adsorbat bisa masuk ke pori, apakah mempunyai luas permukaan yang besar atau apakah ada situs-situs aktif yang dapat beriteraksi dengan adsorbat. Adsorpsi ada dua jenis yaitu adsoprsi fisik dan adsorpsi kimia, banyak hal yang membedakan kedua jenis adsorpsi ini seperti ikatan adsorbat-adsorben, energi aktivasi, lapisan yang terbentuk pada permukaan adsorben dan sebagainya (Adamson, 1990). 


\section{METODE PENELITIAN}

Sampel kerosin diambil dari kilang minyak PPT Migas Cepu, berat karbon aktif yang digunakan divariasi dan karbon aktif dikontakkan dengan kerosin selama waktu tertentu, waktu kontak juga divariasi sehingga dapat ditentukan berat karbon aktif dan waktu kontak optimum. Karbon aktif yang digunakan berasal dari tempurung kelapa yang dibuat oleh PT Indo Huna Charcoal Yogyakarta. Parameter yang diukur adalah kandungan sulfur, bilangan iod dan warna.

Alat yang digunakan berupa alat-alat gelas, timbangan, Unit Sulfur Lamp Method (ASTM D 1266-87), alat pengocok Wrist Action Shaker model 75 Burell, Ayakan Karl Scientific Technical Supplier, Saybolt Chromometer Method (ASTM D 156-87).

Bahan yang digunakan adalah Kerosin, karbon aktif, $\mathrm{H}_{2} \mathrm{O}_{2} 1,5 \%, \mathrm{NaOH} 0,05 \mathrm{~N}$, indikator metil merah, $\mathrm{Na}_{2} \mathrm{~S}_{2} \mathrm{O}_{3} 0,1 \mathrm{~N}$, Aquades, gas $\mathrm{CO}_{2}$ dan $\mathrm{O}_{2}$, $\mathrm{K}_{2} \mathrm{Cr}_{2} \mathrm{O}_{7}, \mathrm{HCl}$, amilum , $\mathrm{Na}_{2} \mathrm{CO}_{3}, \mathrm{KI}$ dan $\mathrm{I}_{2}$.

\section{Cara Kerja}

Karbon aktif ditimbang sebanyak 20, 50, 100, 150, 170 dan 200 gram, dimasukkan kedalam erlenmeyer dan kedalam masing-masing erlenmeyer tersebut dimasukkan kerosin sebanyak $200 \mathrm{ml}$ kemudian dikocok dengan kecepatan tertentu selama 30 menit. Campuran selanjutnya disaring dan ditentukan kandungan sulfur dan warna. Waktu kontak (pengocokan) divariasi sedangkan berat karbon aktif yang digunakan adalah berat optimum.

Kandungan sulfur dalam fraksi kerosin sebelum dan sesudah adsorpsi diukur menggunakan Unit Sulfur Lamp Method. Hal ini merupakan prosedur penetapan total sulfur dalam hasil-hasil minyak bumi dengan konsentrasi antara 0,01 sampai 0,4 persen berat. Metoda ini menggunakan proses pembakaran langsung dengan nyala lampu. Oksida sulfur yang terbentuk dioksidasi oleh $\mathrm{H}_{2} \mathrm{O}_{2}$ sehingga terbentuk $\mathrm{H}_{2} \mathrm{SO}_{4}$ selanjutnya senyawa sulfat ditentukan menggunakan metoda volumetri, $\mathrm{NaOH}$ sebagai larutan standard dan metil merah sebagai indikator.

Bilangan iod ditentukan untuk mempelajari daya adsorpsi karbon aktif setelah digunakan sebagai adsorben. Iodium dikontakkan dengan karbon aktif, dikocok , didiamkan, disaring dan filtrat dititrasi dengan $\mathrm{Na}_{2} \mathrm{~S}_{2} \mathrm{O}_{3}$ dengan indikator amilum.

Saybolt chromometer digunakan untuk analisis warna, sampel dimasukkan kedalam alat dan dibandingkan dengan warna standard.

\section{HASIL DAN PEMBAHASAN}

Proses adsorpsi dilakukan dalam dua tahap, tahap pertama adalah proses menggunakan berat karbon bervariasi sedangkan waktu kontak dikonstankan (30 menit), diukur parameter sehingga dapat ditentukan berat karbon aktif optimum.

Tahap kedua adalah proses dengan memvariasikan waktu kontak, berat karbon aktif yang digunakan adalah berat optimum sehingga dapat ditentukan waktu kontak optimum.

Proses adsorpsi dilakukan di dalam alat pengocok Wrist Action Shaker model 75 Burell, dengan kecepatan pada skala 3, diharapkan kontak antara kerosin dengan karbon aktif menjadi optimal. 
Tabel 1: Pengaruh berat karbon aktif terhadap kandungan sulfur kerosin

\begin{tabular}{cccc}
\hline No & $\begin{array}{c}\text { Berat Karbon } \\
(\text { Gram })\end{array}$ & $\begin{array}{c}\text { [Sulfur] } \\
(\% \mathbf{W})\end{array}$ & $\begin{array}{c}\text { Kualitas } \\
\text { Warna }\end{array}$ \\
\hline 1. & ---- & 0,0310 & +16 \\
& $($ Kerosin awal $)$ & & \\
2. & 20 & 0,0265 & +27 \\
3. & 50 & 0,0260 & +27 \\
4. & 100 & 0,0235 & +28 \\
5. & 150 & 0,0230 & +29 \\
6. & 170 & 0,0230 & +29 \\
7. & 200 & 0,0235 & +29 \\
\hline
\end{tabular}

Pada tabel 1 dapat dilihat bahwa terjadi pengurangan kandungan sulfur dalam kerosin. Senyawa sulfur yang ada dalam kerosin umumnya berupa merkaptan (R-S-H) dan dialkil sulfit (R-S-R), rantai alkil (R) umumnya terdiri dari 4 sampai 5 atom $\mathrm{C}$, dapat berupa rantai lurus, bercabang serta berbentuk siklis, oleh karena itu sangat dimungkinkan senyawasenyawa ini dapat teradsorpsi dan masuk ke dalam pori-pori karbon aktif. Kandungan sulfur semakin berkurang dengan naiknya berat karbon aktif yang digunakan dan akan stabil pada 150 gram sehingga 150 gram ditetapkan sebagai berat karbon aktif optimum. Kualitas warna kerosin semakin meningkat dengan naiknya berat karbon aktif, peningkatan ini mencapai $81 \%$ yaitu dari +16 (gelap) menjadi +29 (jernih) dengan berat karbon aktif 150 gram. Pengurangan kandungan sulfur dan kenaikan kualitas warna kerosin ini menunjukkan bahwa telah terjadi proses adsorpsi senyawa penyebab bau dan warna oleh kerosin. Senyawa tersebut berupa senyawa organik sulfur, nitrogen dan oksigen yang tersisa karena proses distilasi yang kurang sempurna, serta bahan hasil kondensasi berbagai molekul yang disebut gum. Hasil tersebut di atas belum merupakan hasil yang optimum karena waktu kontak yang digunakan hanya 30 menit sehingga perlu dilakukan variasi waktu kontak, hasil dapat dilihat pada tabel 2.

Tabel 2. Pengaruh waktu kontak terhadap kandungan sulfur dan kualitas warna.

\begin{tabular}{cccc}
\hline No & $\begin{array}{c}\text { Waktu Kontak } \\
\text { (Menit }\end{array}$ & $\begin{array}{c}{[\text { Sulfur }]} \\
(\% \mathrm{~W})\end{array}$ & $\begin{array}{c}\text { Kualitas } \\
\text { Warna }\end{array}$ \\
\hline 1. & ---- & 0,0310 & +16 \\
& $\begin{array}{c}\text { Kerosin } \\
\text { Awal) }\end{array}$ & & \\
2. & 20 & 0,0295 & +19 \\
3. & 30 & 0,0235 & +28 \\
4. & 40 & 0,0230 & +29 \\
5. & 70 & 0,0230 & +30 \\
6. & 80 & 0,0210 & +30 \\
7. & 90 & 0,0215 & +30 \\
\hline
\end{tabular}

Kandungan sulfur semakin berkurang dengan naiknya waktu kontak, pada 40 menit dan 70 menit sudah menunjukkan kandungan sulfur yang konstan tetapi pada 80 menit kandungan sulfur semakin berkurang menjadi 0,0210 dengan pengurangan sebesar $32,2 \%$. Kualitas warna meningkat semakin jernih yaitu +30 (jernih seperti aquades) dengan peningkatan sebesar $87,5 \%$. Kecendrungan ini menjelaskan bahwa molekul-molekul yang lebih kecil penyebab warna lebih mudah dan lebih banyak terserap dari pada senyawa sulfur yang lebih besar, dialkilsulfit akan lebih susah masuk pori dibandingkan merkaptan, karena banyaknya komponen pengotor sehingga apabila pori sudah terisi oleh molekul kecil akan menghambat masuknya molekul yang lebih besar. Proses adsorpsi sangat dipengaruhi oleh ukuran pori adsorben sehingga untuk meningkatkan penurunan kandungan sulfur perlu dilakukan pemilihan karbon aktif dengan ukuran pori yang lebih besar.

Untuk membuktikan bahwa sudah terjadi proses adsorpsi oleh karbon aktif maka dilakukan pengukuran bilangan Iod karbon aktif. Bilangan iod merupakan ukuran kemampuan karbon aktif 
untuk mengadsorpsi dan didefinisikan sebagai banyaknya Iod (miligram) yang diserap oleh 1 gram karbon aktif. Bilangan Iod karbon aktif awal (sebelum digunakan) adalah 1077 dan setelah digunakan bilangan Iod turun menjadi 872 yaitu turun $19 \%$. Hal ini menunjukkan telah berkurang kemampuan karbon aktif untuk mengadsorpsi iod karena pori-pori karbon aktif sudah terisi oleh komponen yang ada dalam kerosin

\section{KESIMPULAN}

Dari hasil penelitian dapat disimpulkan:

1. Karbon aktif dari tempurung kelapa produksi PT Indo Huna Charcoal dapat menurunkan kandungan senyawa sulfur $32,2 \%$ dan meningkatkan kualitas warna sebesar 87,5\%.

2. Mutu kerosin dapat ditingkat melalui proses adsorpsi oleh karbon aktif baik dari segi bau maupun warna

\section{DAFTAR PUSTAKA}

Adamson,A.W., 1990, Physical Chemistry, Sounders College Publ, USA.

Cheremisinoff, P.N., 1978, Carbon Adsorption Handbook, Ann Arbor Science Publ Inc, Michigan.

Hardjono, 1987, Teknologi Minyak Bumi I, edisi kedua, Jurusan Teknik Kimia Universits Gajah Mada, Yogyakarta.

Jankowska, H., Swiatkowski, A and Choma, J., 1991, Active Carbon, Ellis Horwood Limited, England.

Kirk-Otthmer, 1967, Encyclopedia of Chemical Technology, $2^{\text {nd }}$, John Wiley and Sons Publ Inc, USA.

Lynam, N. M., 1995, Adsorption of pNitrophenol from Dilute Aqueous Solution, J. Chem. Edu., vol 72, no. 1, Januari, p. 80-84.

Surdia, N. M., 1992, Pengantar Kimia Permukaan dan Kimia Koloid, Depdikbud, Jakarta. 